\title{
Edukasi Metode BE-FAST Meningkatkan Self AwarenesS Terhadap Deteksi Dini Stroke
}

\author{
${ }^{1}$ Galvani Volta Simanjuntak, ${ }^{2}$ Jek Amidos Pardede, ${ }^{3}$ Janno Sinaga \\ 123 Universitas Sari Mutiara Indonesia \\ Korespondensi: jekpardedemi@rocketmail.com
}

\begin{abstract}
Hypertension is a precipitating factor of stroke. Growing self awareness of the importance of early detection can be an effort to reduce the risk of stroke in people with hypertension. One of the early detection methods for stroke patients is "BE-FAST" (Balance, Eyes, Face, Arm, Speech, \& Time). The purpose is to grow selfawareness of early stroke detection using the BE-FAST method. This activity is carried out by health promotion through education about BE-FAST with the lecture method. This activity was attended by 27 people with hypertension. The results of the evaluation showed that the knowledge of the participants in the activity increased after the education was carried out. Increased knowledge along with increasing self-awareness so that people with hypertension are expected to routinely carry out early detection with the BE-FAST method to reduce the risk of stroke.
\end{abstract}

Keywords: BE-FAST, Hypertension, Self Awareness, Stroke

\begin{abstract}
Abstrak:Hipertensi merupakan faktor pencetus terjadinya stroke. Menumbuhkan self awareness pentingnya deteksi dini dapat menjadi upaya untuk mengurangi risiko terjadinya stroke pada orang dengan hipertensi. Salah satu metode deteksi dini untuk penderita stroke adalah metode BE-FAST (Balance, Eyes, Face, Arm, Speech, \& Time). Tujuan dari kegiatan pengabdian masyakat ini adalah untuk menumbuhkan self awareness deteksi dini stroke menggunakan metode BE-FAST. Kegiatan ini dilakukan dalam bentuk promosi kesehatan melalui edukasi tentang BEFAST dengan metode ceramah. Sasaran kegiatan ini adalah penyandang hipertensi. Kegiatan ini diikuti oleh 27 orang. Hasil evaluasi menunjukkan bahwa pengetahuan peserta kegiatan meningkat setelah dilakukan edukasi. Meningkatnya pengetahuan seiring dengan meningkatnya self awareness sehingga diharapkan penyandang hipertensi rutin melakukan deteksi dini dengan metode BE-FAST guna menurunkan risiko terjadinya stroke.
\end{abstract}

Kata Kunci: BE-FAST, Hipertensi, Self Awareness, Stroke

\section{PENDAHULUAN}

Hipertensi merupakan salah satu penyakit kardiovaskuler yang paling umum dan banyak diderita oleh masyarakat di Indonesia ${ }^{1}$. Tidak hanya di Indonesia, hipertensi juga menjadi masalah kesehatan utama di seluruh dunia ${ }^{2}$. Hal ini dikarenakan hipertensi merupakan salah satu pintu masuk atau faktor risiko penyakit seperti jantung, gagal ginjal, dan stroke yang menjadikan penyakit ini menjadi penyebab kematian nomor satu di dunia setiap tahunnya.

Angka kejadian hipertensi terus mengalami peningkatan setiap tahunnya. Data Riset Kesehatan Dasar tahun 2018 mendapatkan bahwa prevalensi hipertensi di Indonesia sebesar 34,1\%. Ini mengalami peningkatan dibandingkan prevalensi hipertensi pada Riskesdas Tahun 2013 sebesar 25,8\%. Estimasi jumlah kasus hipertensi di Indonesia sebesar 63.309.620 orang, sedangkan angka kematian di Indonesia akibat hipertensi sebesar 427.218 kematian $^{3}$. Seseorang didiagnosis hipertensi jika hasil pengukuran tekanan darah menunjukkan hasil tekanan sistol (angka yang pertama) $\geq 140 \mathrm{mmHg}$ dan/atau tekanan diastol (angka yang kedua) $\geq 90 \mathrm{mmHg}$ pada lebih dari 1(satu) kali kunjungan. Hipertensi merupakan Faktor Pencetus Terjadinya Stroke. Suatu penelitian mendapatkan bahwa sekitar $60 \%$ penderita hipertensi berakhir pada stroke terutama stroke iskemik ${ }^{4}$. 
Menumbuhkan kesadaran dan kewaspadaan diri sangat penting dalam upaya pencegahan terjadinya komplikasi suatu penyakit. Kesadaran diri atau self-awareness adalah perhatian terhadap diri sendiri, kesiapan untuk mengenali diri sendiri terhadap apa yang dilakukan, dan pemahaman tentang lingkungan yang ada di sekitar kita. Self-awarness merupakan kunci sebuah perubahan di dalam hidup seseorang ${ }^{5}$. Kesadaran seseorang mengenai pentingnya melakukan deteksi dini dapat menjadi upaya untuk mengurangi risiko terjadinya stroke, melalui metode BE-FAST yakni, Balance (keluhan kehilangan keseimbangan atau pusing atau kepala yang berat sehingga cenderung berpegangan pada sesuatu atau duduk., Eyes (keluhan penglihatan menjadi kabur), Face (keluhan wajah tampak tidak normal seperti turun sebelah dan tidak simetris), Arm (keluhan lengan menjadi lemah), Speech (keluhan bicara menjadi sulit, tidak jelas, atau bahkan tidak bisa bicara), Time (Jika mendapatkan keluhan diatas, segera kerumah sakit) $)^{6}$.

Metode BEFAST sangat sensitive untuk skrining stroke iskemik akut dengan angka prediksi $>95 \% 6,7$, Oleh karena itu, Promosi Pendidikan Kesehatan terkait metode BE-FAST sangat penting dilakukan sebagai bentuk proteksi dasar untuk mencegah terjadinya stroke, temuan tersebut dapat dikaitkan dengan pendidikan promosi kesehatan yang akan dilakukan oleh penulis dengan metode edukasi secara virtual kepada penyandang hipertensi. Dalam kegiatan ini yang akan menjadi sasaran penulis adalah masyarakat dengan hipertensi di wilayah kerja Puskesmas Hutagalung.

\section{METODE PELAKSANAAN}

Penyampaian materi tentang Metode BEFAST dalam kegiatan ini menggunakan metode Ceramah. Metode ini dipilih guna mempermudah peserta didik untuk memahami isi dari materi yang disampaikan oleh narasumber sebagai informasi kesehatan yang penting sehingga setelah ceramah dilakukan, diharapkan peserta didik dapat memahami, mengingat, sekaligus mendapatkan gambaran bagaimana cara melaksanakan metode BEFAST dengan benar. Sasaran pendidikan dan promosi kesehatan mengenai edukasi metode BE-FAST yaitu masyarakat penyandang hipertensi di wilayah kerja Puskesmas Hutagalung Pelaksanaan kegiatan ini dilakukan secara daring dengan menggunakan aplikasi zoom meeting.

Promosi kesehatan melalui pendidikan kesehatan ini diharapkan dapat membuat penyadang hipertensi di wilayah Puskesmas Hutagalung meningkat kesadaran dirinya sehingga menerima dan mau melaksanakan metode BE-FAST. Tahapan dalam pelaksanaan kegiatan promosi kesehatan ini, meliputi tahap persiapan (menyiapkan segala alat dan perlengkapan untuk kegiatan), tahap pelaksanaan (pembukaan, pemberian materi dan penutup), dan tahap evaluasi (evaluasi proses dan evaluasi hasil).

\section{HASIL DAN PEMBAHASAN}

Hasil kegiatan pengabdian kepada masyarakat didapatkan 27 peserta yang mengikuti kegiatan.

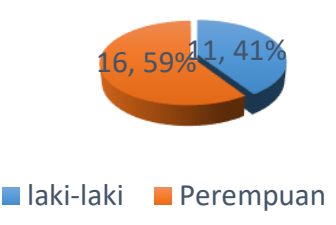

Gambar 1. Karakteristik Peserta Kegiatan Berdasarkan Jenis Kelamin 
Selama kegiatan berlangsung, para peserta kegiatan tampak serius dan antusias mendengarkan informasi yang disampaikan oleh tim. Saat sesi diksusi/tanya jawab, peserta juga antusias bertanya tentang hal yang mereka belum pahami, paling banyak peserta bertanya pada bagian keluhan di Balance (B) dan Eye (E). Untuk melakukan evaluasi, sebelum dan setelah kegiatan, tim memberikan 10 pernyataan terkait metode BE-FAST. Hasil evaluasi dapat dilihat pada gambar 2.

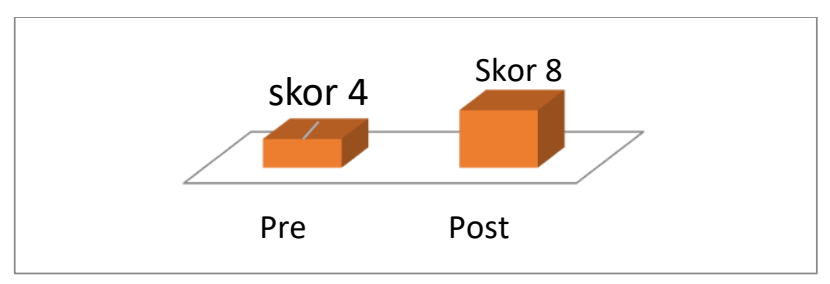

Gambar 2. Rata-rata jawaban benar sebelum dan setelah edukasi

Pengetahuan dan kemampuan masyarakat dalam melakukan deteksi dini stroke dinilai dengan kuesioner yang terdiri dari 10 pernyataan yang berkaitan dengan metode BE-FAST. Sebelum diberikan edukasi, rata-rata peserta menjawab benar 4 dari 10 pernyataaan. Hal ini menunjukan bahwa penyandang hipertensi memiliki pengetahuan yang minim tentang metode BE-FAST. Strategi pencegahan dan pengurangan stroke membutuhkan pengetahuan dan pemahaman yang baik. Pengetahuan dan pemahaman penyandang hipertensi sangat diperlukan sebagai dasar untuk berperilaku.

Setelah diberi edukasi, pengetahuan dan pemahaman peserta meningkat ditandai dengan meningkatnya rata-rata jawaban benar para peserta dari skor 4 menjadi skor 8 . Hal ini menunjukkan bahwa informasi tentang metode BE-FAST diterima dengan baik oleh para peserta. Hal ini menunjukkan bahwa informasi yang disampaikan dengan metode ceramah pada kegiatan ini dapat diterima dengan baik oleh peserta. Ceramah merupakan cara yang paling alamiah untuk berkomunikasi dengan orang lain, yaitu dengan cara berbicara secara langsung sehingga pendengar dapat dengan mudah memahami informasi yang disampaikan.

Pengetahuan adalah hasil penginderaan manusia, atau hasil tahu seseorang terhadap objek melalui indera yang dimilikinya (mata, hidung, telinga, dan sebagainya) ${ }^{8}$ dan pengetahuan merupakan domain terpenting dalam terbentuknya perilaku. Hal tersebut menjelaskan bahwa perilaku deteksi dini dengan metode BE-FAST akan dilakukan dan terlaksana dengan baik bila metode BE-FAST telah dipahami dengan baik oleh penyandang hipertensi. Hasil evaluasi kegiatan menunjukkan bahwa pengetahuan dan pemahaman tentang metode BE-FAST meningkat setelah diberikan edukasi. Sebelum dilakukan edukasi, kebanyakan peserta salah menjawab tentang gangguan keseimbangan, pusing atau kepala terasa berat, penurunan penglihatan sebagai salah satu gejala stroke serta kelemahan lengan. Setelah dilakukan edukasi, peserta memahami bahwa gangguan keseimbangan, penurunan fungsi penglihatan dan melemahnya lengan merupakan salah satu gejala awal stroke. Peserta juga memahami jika mengalami gejala tersebut, segera ke rumah sakit.

Peningkatan pengetahuan ini seiring dengan peningkatan self awareness peserta untuk melakukan deteksi dini stroke. Meningkatnya self awareness membuat Penyandang Hipertensi menyadari akan pentingnya deteksi dini sebagai bentuk proteksi dasar untuk mencegah terjadinya stroke sehingga setelah kegiatan ini Penyandang Hipertensi rutin untuk melakukan metode BE-FAST. 


\section{KESIMPULAN}

Telah dilakukan pengabdian masyarakat yaitu kegiatan promosi kesehatan dengan edukasi tentang deteksi dini stroke dengan metode BE-FAST untuk meningkatkan self awareness guna mencegah stroke pada penyandang hipertensi. Kegiatan ini dihadiri diikuti 27 peserta. Berdasarkan evaluasi, didapatkan bahwa rata-rata jawaban benar peserta meningkat dari sebelum edukasi rata-rata 4 meningkat menjadi 8 setelah edukasi. Dengan meningkatnya pengetahuan, diharapkan penyandang hipertensi memiliki self awareness yang tinggi sehingga rutin untuk melakukan deteksi dini dengan metode BE-FAST guna menurunkan risiko terjadinya stroke.

\section{UCAPAN TERIMAKASIH}

Terimakasih kami ucapkan kepada Pihak Puskesmas Hutagalung, masyarkat, dan seluruh orang yang terlibat pada pengabdian masyarakat ini.

\section{DAFTAR PUSTAKA}

1. Triana, D., \& Hardiansyah, H. Promosi Kesehatan Mengenai Hipertensi Dan Pemeriksaan Laboratorium Di Kelurahan Sumur Dewa Kota Bengkulu. Dharma Raflesia: Jurnal Ilmiah Pengembangan Dan Penerapan IPTEKS, 2021 Juni; 19(1), 41-48.

2. KemenkesRI. Hasil utama RISKESDAS 2018. In Badan Penelitian dan Pengemb Kesehatan, Kementrian Kesehatan Republik Indonesia. 2019. Available from: https://www.litbang.kemkes.go.id/laporan-riset-kesehatan-dasar-riskesdas/

3. KemkesRI. Hipertensi Penyakit Paling Banyak Diidap Masyarakat.2019 June 17. Available from: https://www.kemkes.go.id/article/view/19051700002/hipertensi-penyakit-paling-banyak-diidapmasyarakat.html

4. Yonata A, Pratama AS. Hipertensi sebagai faktor pencetus terjadinya stroke. Jurnal Majority. 2016;5(3):17-21.

5. Eriyani T, Shalahuddin I, Rosidin U. Edukasi 3m Dalam Meningkatkan Self-Awareness Terhadap Penyebaran Covid-19 Di Smkn 4 Garut. Kumawula: Jurnal Pengabdian Kepada Masyarakat. 2021 May $10 ; 4(1)$.

6. El Ammar F, Ardelt A, Del Brutto VJ, Loggini A, Bulwa Z, Martinez RC, McKoy CJ, Brorson J, Mansour A, Goldenberg FD. BE-FAST: a sensitive screening tool to identify in-hospital acute ischemic stroke. Journal of Stroke and Cerebrovascular Diseases. 2020 Jul 1;29(7):104821.

7. Aroor S, Singh R, Goldstein LB. BE-FAST (Balance, Eyes, Face, Arm, Speech, Time) reducing the proportion of strokes missed using the FAST Mnemonic. Stroke. 2017 Feb;48(2):479-81.

8. Notoatmodjo, S. Promosi Kesehatan \& IImu Perilaku. Rineka Cipta.2014 